\title{
Measuring internationality: Reflections and perspectives on academic journals
}

\author{
Gualberto Buela-Casal, ${ }^{a}$ PANDelis Perakakis, ${ }^{a}$ Michael Taylor, ${ }^{b}$ \\ PURIFICACIÓN CHECA ${ }^{\text {a }}$ \\ a Department of Psychology, University of Granada, Granada (Spain) \\ ${ }^{\mathrm{b}}$ Department of Theoretical Physics, Autonomous University of Madrid, Madrid (Spain)
}

\begin{abstract}
Internationality as a concept is being applied ambiguously, particularly in the world of academic journal publication. Although different criteria are used by scientometrists in order to measure internationality and to supplement its minimal literal meaning, the present study suggests that no single criterion alone is sufficient. This paper surveys, critically-assesses and extends the existing measures of internationality in the context of academic publishing and identifies those criteria that are most clearly resolved and amenable to quantitative analysis. When applied, however, to a case study of four thematically-connected journals from the field of Health and Clinical Psychology using descriptive statistics and the Gini Coefficient, the measurement of internationality using these criteria was found to be ambiguous. We conclude that internationality is best viewed as a mathematically fuzzy entity and that a single measure Internationality Index, constructed from a combination of suitably weighted criteria, is the only way to unambiguously quantify the degree of internationality.
\end{abstract}

\section{Introduction}

Although the technological developments in the electronic era have introduced new modes of interaction between academics, publications in academic journals, either in print form or online, remain a vital element in the process of academic communication and evaluation. In particular, publications in prestigious journals are used as important quality indicators. This emphasizes the need for carefully contemplated criteria and quantitative indices to assess journal information.

Several criteria have been proposed; one of them being the internationality of a journal. This criterion is constantly receiving more attention in a world that is tending toward a globalization of ideas. Thus, a single quantitative measure of internationality in the form of an internationality index, akin to the Journal Impact Factor, would be an indispensable tool in the hands of authors, readers, editors, publishers and generally anyone interested in the evaluation of journals and consequently of the articles

Received July 11, 2005

Address for correspondence:

GUALBERTO BUELA-CASAL

Faculty of Psychology, University of Granada, Campus Universitario Cartuja, 18011 Granada, Spain

E-mail: gbuela@ugr.es

0138-9130/US \$20.00

Copyright @ 2006 Akadémiai Kiadó, Budapest

All rights reserved 
published in such journals. In this paper, we lay the foundation for the possible development of such an index by identifying its principal components.

It should be made clear that internationality per se is not to be equated with quality. It is quite possible that a non-global, non-international journal may publish the best, most advanced and innovative research. We speculate, however, that journals with wider national representation could increase the diversity of ideas and criticisms and be beneficial to the advancement of knowledge. Therefore, in this paper we focus on the identification of a complete set of factors necessary to accurately define and measure internationality in relation to academic journals publishing.

We first reveal the problems associated with the lack of a suitable definition of Internationality or International Journal and address common misconceptions. Then, the criteria that have been used to measure Internationality are presented, extended and critically assessed. We identify those criteria that form a set of well-defined and quantifiable measures and use them in a document analysis of journal articles from the thematic area of Clinical and Health Psychology. This analysis leads to the conviction that internationality is best viewed as a fuzzy set comprising several weighted factors, an approach that could allow the construction of an unambiguous and quantifiable measure of Internationality in the form of an Internationality Index. We conclude with a review of our findings and a perspective for the future of internationality.

\section{Internationality and international journal: Undefined concepts}

Two central problems facing the measurement of the internationality of academic journals are:

1. Global under-representation as a result of the use of the literal definition of the word international in its minimal sense and,

2. Widespread usage of the term international without any evaluation of its degree with reference to appropriate measures or indices.

The first is a linguistic problem which arises from the literal meaning of the word "international". Literally, international means "relating to, or affecting two or more nations". ${ }^{1}$ Thus, a product of the collaboration between two countries would qualify as international. This is an observation that should always be kept in mind when discussing internationality and academic journals, since it is obvious that there is a great difference between a journal publishing articles by authors from two neighboring countries and another journal publishing authors from all over the globe; i.e. multinational. Nevertheless, both of these journals would literally be classified as international with regard to authorship. In the literature it is common to see scientometrists using the terms "international" and "multinational" interchangeably with multinational loosely meaning "more international". This vagueness, we argue is due to 
the lack of clear definition of what international is or means. Generally, when contemplating an international journal one expects that it not only fulfills the literal definition, but that it also reflects a global perspective. This suggests the need for a quantitative index to evaluate the degree of internationality.

The second problem is that, in spite of the literal ambiguity around the term "international", the characterization international is also being used extensively without qualification. Although this could clearly manifest itself in many distinct disciplines, we would like to give some examples from the area of Social and Behavioural Sciences to illustrate the point.

\section{Internationality as perceived in Social and Behavioural Sciences}

The Encyclopedia of Psychology of the American Psychological Association, for example, does not define "international journal" rather, it describes other related terms that can help us appreciate the concept of international in relation to journals. Thus, for example, Holtzman ${ }^{2}$ asserts that "international psychology" refers to "scientific or professional activities (organizations, exchanges, and research enterprises) of a psychological nature involving groups of psychologists in two or more nations". Wilpert ${ }^{3}$ claims that the constitutional aims of the International Association of Applied Psychology (IAAP) are to "establish contact among those who, in different countries, devote themselves to scientific work in various fields of applied psychology...". Davis ${ }^{4}$ indicates that the purpose of the International Council of Psychologists (ICP) is "to advance psychology as a worldwide discipline. The ICP promotes international communication, understanding, and cooperation among individual psychologists of all nationalities and fields of interest", and Hambleton ${ }^{5}$ states that the International Test Commission is an association of 24 national psychological societies "which have an interest in improving tests and testing practices around the world". But why should 24 societies alone be globally-representative?

The International Encyclopedia of the Social and Behavioral Sciences, whose very title includes the word "international" and which has a multinational publishing committee, does not define what an "international journal" is. The most relevant reference in the encyclopedia is by $\mathrm{Haas}^{6}$ who defines international organization (IO) as having: "norms of conduct and processes of interaction among more than six thousand (1999) concrete organizations and their members, bureaucracies wishing to attain objectives that are seen by them as unrealizable without cooperating across political and organizational boundaries". In the same encyclopedia, Jacobson, ${ }^{7}$ when describing the term "international sciences" speaks about "the formal infrastructure that supports and promotes international collaboration in the social and behavioral sciences which consists of several associations based on disciplines or sub-disciplines: the International Social Science Council (ISSC) and to a certain extent the International Council for 
Science". Again no guideline is given as to when it is appropriate to use the term "international". Furthermore, when reviewing a specialized manual such as the International Handbook of Psychology, ${ }^{8}$ and other specific chapters on international psychology such as those by $\mathrm{Jing}^{9}$ or David and Buchanan, ${ }^{10}$ we encountered only an implicit or explicit statement that "international" refers to "several countries".

These examples illustrate that, although the term "international" (referring or not to journals) is widely used, this is being done without qualification or any reference to quantitative indices. Instead we mostly encounter the term in its literal meaning (relating to two or more nations), or with other subjective interpretations such as: "different countries", "around the world", "worldwide", etc. Nevertheless, a range of criteria have been proposed to assess journal internationality. ${ }^{11-13}$ What follows is a brief discussion of these criteria, supplemented by additional criteria that we have identified in order to establish a coherent set as a basis for a quantitative measure and therefore, a more precise definition of internationality in the context of assessing academic journals.

\section{Internationality criteria}

One of the principal aims of this work is to construct a more accurate and complete set of criteria that could be used to measure the degree of internationality. The criteria listed below have been collected from the literature and assessed. As we will argue, some criteria do not play an important role in the assessment of internationality. We have included additional criteria which we believe enhance and extend the set.

\section{Publication language}

The publication language (or languages) affects linguistic accessibility and therefore a journal's internationality due to the geographical distribution of readers. When considering this criterion we find three parameters that are crucial in the assessment of each language's influence on a journal's internationality:

1. the percentage of the world population speaking each language,

2. the number of countries where the language is official, and,

3. the academic impact of the language or languages used.

According to data taken from the New York Times Almanac 1988, Chinese (Mandarin) is the most widely spoken language in the world $(14.75 \%$ of the world population), followed by Spanish (5.53\%) and then English (5.37\%). A journal publishing all of its articles in all three of these languages would be linguistically open to $25.65 \%$ of the world population.

Concerning the number of countries where each language is official, the English language is most prevalent (51 countries), followed by Spanish (20 countries). 
A journal therefore publishing its articles in these two languages would provide linguistic access to readers from $37 \%$ of the official world states.

Finally, it has been suggested that English, being the native language of two of the most scientifically productive countries in the world (the USA and the UK) is the language having the greatest academic impact. A recent study has demonstrated that a change of the publication language from German to English in two German psychology journals led to a significant increase in the rate of articles published by foreign authors. ${ }^{14}$ Nevertheless, it is difficult to objectively assess the academic repercussion of a given language since, for example, the Latindex database ${ }^{15}$ includes 13,364 registered academic journals published in Spanish and/or Portuguese which is significantly more than the 8.700 journals published in English cited in the Journal Citation Reports. ${ }^{16}$ Moreover, one should keep in mind those socio-political effects that bias or bar access to publication such as externally-imposed embargoes or internally-imposed controls on distribution and access through censorship, classification, copyrighting and patenting.

What is apparent is that a journal's publication language is an important although hard to quantify criterion and that publishing in the English language alone is not a sufficient condition to classify a journal as being international.

\section{Publication country}

A journal's publication country does not affect its internationality and a journal published in a foreign country is nothing more than a foreign journal. If this was not the case, a Japanese journal would be international for a French reader, and simultaneously a French journal would be international for a Japanese reader, while both would be international for a Greek reader. Publication country then, is a criterion used by those who confuse "international" with "foreign". A journal, however, published in several different countries simultaneously and in different language editions would be more international; something that could be facilitated with the advent of online journals and the development of intelligent, electronic translation software, in conjunction with increased global access to internet technology.

\section{Inclusion of the term "international" in the title}

Although this seems a reasonable criterion to consider as a qualitative index for assessing internationality, encyclopedias, associations and academic committees, often include the term "international" in the title of their journals without justification of which norms are implemented to qualify them as international. Hence, the denomination "international journal" does not guarantee internationality or global perspective. 


\section{Inclusion in international databases}

This criterion is extensively used but is an unreliable measure of internationality since the journals that are included in international databases such as PsycLIT, Medline, ERIC or Ingenta, are not necessarily international in nature. This criterion however, does affect the diffusion of knowledge and awareness of publications and therefore has a bearing on the multinational distribution of readers and journal users, and hence, on international accessibility.

\section{The Impact Factor}

It has been demonstrated ${ }^{17-19}$ that in most research academic areas, multinational collaboration results in greater visibility and higher citation rates. Thus, there is an empirically-confirmed positive correlation between internationality measured by multinational collaboration and Impact Factor. This does not mean however, that there is a causal relationship between citation impact and internationality. The inclusion of a journal in the catalogue of Journal Citation Reports, which automatically assigns to it an Impact Factor based on citation analysis, does not imply anything about internationality in terms of journal content or with respect to the multinational distribution of authors. Besides, Buela-Casal et al. ${ }^{20}$ have recently demonstrated that journals exist which are not published in English nor are included in the Journal Citation Reports and yet have a considerable Impact Factor.

Even though the Impact Factor has been the subject of various critiques not only for its invalidity, ${ }^{21-26}$ but also due to particular deficiencies with respect to the recommended number of references per article ${ }^{27,28}$ and the number of self-references, ${ }^{29}$ in this article we do not wish to judge it as a quality indicator, rather to indicate its inadequacy in accounting for a journal's internationality.

\section{Affiliation to an international institution or association}

It may seem logical that a journal published by an association with an international reputation would be an international journal, but this depends sensitively on the internationality of the parent institution or association. Furthermore, affiliation to an international institution or association typically ensures the use of international publication norms; norms which, however, do not explicitly refer to international publishing criteria such as the national makeup of journal committees or the geographical distribution of authors, and are therefore not a sufficient guarantee of internationality. In this sense, to consider a priori that all of the journals published by, for example, the American Psychological Association as international is no less than a clear "Americanization" as opposed to "internationalization" of psychology. This is in 
agreement with the idea of "academic colonization" emphasized by various authors. ${ }^{10,30,31}$ The issue here seems to be a dominance of Anglo-Saxon culture ${ }^{32,33}$ in academic publishing reflecting the western-dominated globalization of the past few decades.

\section{Multinational distribution of the editorial board members}

This refers to the international composition of editorial boards and is another of the most commonly mentioned criteria referring to journals internationality. ${ }^{34}$ Obviously, an editorial board comprising reviewers from various countries facilitates that the revision of the articles is made from a more international perspective. This criterion however, is not by itself sufficient for a journal to be international since for example, it may draw authors only from a single country. In addition, in several cases, the "international" editorial boards attributed to some academic journals are no more than an adornment since the actual reviewing of articles is performed by editorial members from the host nation of the journal.

Furthermore, we believe that this criterion requires clarification since there is a distinction to be made between the editorial board and the pool of associate editors selected by the editorial board to review articles "out of house". These two groups are often lumped together under the term "editorial committee" in the literature. This distinction is highly pertinent to the degree of internationality when one considers that the external pool of editors tends to be both more numerous and more multinational in nature. In this work, we denote editorial board members as those permanent, "in house" members of the journal and we distinguish them from the pool of associate editors that are selected and are "out of house". In this new sense, we believe that the multinational distribution of editorial board members directly influences the internationality of a journal.

\section{Multinational distribution of the associate editors}

As described in the previous subsection, we have introduced this criterion to reflect the effect on internationality of the associate editors selected by the "in-house" journal editorial boards. In general, the associate editors are drawn from a wider range of countries meaning that they are likely to represent a more global perspective. However, since, in the majority of cases, their role is a secondary one with them reviewing articles selected by the editorial boards, the global filtering bias may have already been introduced at the primary level of the editorial boards. 


\section{Multinational distribution of authors}

This is probably the most common measure of journal internationality. Zitt and Bassecoulard ${ }^{11}$ have argued that there are absolute and relative approaches to calculate degrees of internationality based on the multinational distribution of authors. The absolute approaches use concentration indices that consider the percentage of foreign authors in a journal's total output, ignoring each country's general academic contribution. In this way, absolute indices, such as the Gini coefficient, fail to differentiate between, for example, an 80\% United States: 20\% United Kingdom journal and an $80 \%$ Czech: $20 \%$ Austrian journal. Absolute indices however, are easier to calculate and have been used in relevant studies in the past. ${ }^{35-40}$ Other indices to evaluate relative internationality have been proposed ${ }^{11}$ that use well-contemplated normalization options to avoid biases caused by the different national academic sizes in each area. Nevertheless, the authors also recognize the value of reference-free, concentration indices in providing a wider perspective. Despite the normalization options here, the authors as the central engine of a journal represent one of the key tests of internationality.

\section{Multinational distribution of users}

A journal's users are its readers, subscribers and citers. However, bibliometric research has direct access only to the geographical distribution of citers. Obviously, equalizing citers and users leaves out all readers that are not academic authors as well as the academics that are consulting journals outside their particular research area and so do not cite them in their work. Nevertheless, the majority of the studies that examined this criterion have done so through the analysis of the geographical distribution of citers, making the assumption that it reflects the actual multinational distribution of all journal users. ${ }^{35}$

\section{International collaboration patterns}

A journal's capability to attract multinational collaboration is another useful and extensively investigated criterion. International collaboration is assessed by coauthorship indices that provide information about the share of internationally coauthored papers in a journal's total publication output. ${ }^{41}$ Several authors have investigated such collaboration patterns and co-authorship maps and have provided great insight on the fundamental mechanisms that underlie the dynamics of international cooperation. ${ }^{19,42,43}$ Nevertheless, it has been observed that the international collaboration linkages between academics and research groups are not only influenced by variables such as the inherent cooperation tendencies of the academic community and the 
academic size of each country, but also from sociological, geographical, ideological and other parameters that are especially difficult to quantify. ${ }^{44}$ In this study, in order to attempt a quantitative assessment of this criterion, we use the concept "share of international articles" as a measurable following the example of Rey-Rocha and MartínSempere. ${ }^{45}$ By "international article" we mean an article published by at least two authors affiliated to institutes from two different countries. In this way, we are able to distinguish international articles from purely "domestic" articles published by authors based in the host journal nation, and "foreign" articles with authors based in only one country other than the host (e.g., Ref. 46,47).

\section{Online access}

Since 1996, the vast majority of journals have online archives of their print articles, which could increase global access. Similar to the publication language, online accessibility depends sensitively on the dominant languages used in web pages and electronic journal subscription rates. The journals selected for the bibliometric analysis of the next section all have online access to articles published after 1997.

From the above list, it is clear that there are many criteria commonly used to measure internationality in the context of academic journals, though only a few are relevant to the quantitative measurement of internationality.

\section{Pruning and testing the criteria}

\section{Methodology}

Following the analysis of the set of criteria in the previous section II, we identified the following core sub-set as being the most semantically precise and quantitative, in order to define and measure internationality:

- Criterion 1: Multinational collaboration patterns (assessed through the share of international articles as described in the previous section)

- Criterion 2: Multinational distribution of editorial board members

- Criterion 3: Multinational distribution of associate editors

- Criterion 4: Multinational distribution of authors.

We hypothesized that these criteria would yield different measures of internationality when considered separately. We also wanted to test the generally-held subjective impression that journals published in English from countries having a larger academic size are more international in the context of a well-defined measurement of 
internationality. In order to test our hypotheses, we conducted a thorough bibliometric analysis of four journals from the area of clinical and health psychology:

1. Journal of Clinical Psychology (ISSN: 0021-9762),

2. Health Psychology (ISSN: 0278-6133),

3. International Journal of Clinical and Health Psychology (ISSN: 1576-7329), and,

4. International Journal of Psychology and Psychological Therapy (ISSN: 1577-7057).

These journals were selected since:

- they are all connected thematically

- two of them contain the term "international" in their title

- two are published only in English while the other two are published in English and an additional language (Spanish and/or Portuguese)

- two are US journals, two are Spanish journals

- all journals have online access.

The first two journals which are published in the United States of America are generally considered as two of the most prestigious journals in the area and are typically characterized as international probably based on the scientific quality of the published articles and the multinational distribution of their readers. Their international characterization is also due to their inclusion in highly esteemed and widely used databases. The last two journals on the other hand are published in Spain and although they include the term "international" in their title, are commonly considered as "noninternational" journals. An important point to note here is that the two journal host nations differ substantially in academic size and, although the number of academic nationals is irrelevant to a measure of internationality, the number of academic foreign nationals working in the host nation is not. In fact, one would expect that a country with a large academic size and resources, comprising many locally-based foreign scientists, would have a greater international pool of editors and authors to draw from. However, this is not a guarantee of internationality as it depends sensitively on the international perspective of the journals; which is what we intend to measure.

The raw data is presented using standard techniques of descriptive statistics. We also have used an absolute statistical measure, the Gini Coefficient of inequality ${ }^{48}$ such that a coefficient of 1 represents total inequality while 0 represents total equality. The tabulated raw data used in the determination of these quantitative measures is available online. $^{49}$ 


\section{Results}

In this test of the criteria, a total of 710 articles published by the four journals from 2001-2003 (both inclusive) were analyzed. The descriptive characteristics of the four journals are given in Table 1. It is worth mentioning that the journals examined differ with respect to the number of issues published per year (their annual publication rate).

Table 1. Descriptive statistics of the number of published articles in each journal during the period 2001-2003 (inclusive)

\begin{tabular}{|c|c|c|c|c|c|c|c|c|}
\hline Journal & $\begin{array}{l}\text { Publi- } \\
\text { cation } \\
\text { languages }\end{array}$ & Founded & $\begin{array}{c}\text { Total } \\
\text { number of } \\
\text { published } \\
\text { articles } \\
\end{array}$ & $\begin{array}{c}\text { Publication } \\
\text { frequency } \\
\text { (articles } \\
\text { per year) }\end{array}$ & $\begin{array}{c}\text { Mean } \\
\text { number } \\
\text { of articles } \\
\text { per year } \\
\end{array}$ & $\begin{array}{l}\text { Standard } \\
\text { deviation }\end{array}$ & $\begin{array}{c}\text { Mean number } \\
\text { of articles } \\
\text { per issue }\end{array}$ & $\begin{array}{l}\text { Standard } \\
\text { deviation }\end{array}$ \\
\hline $\begin{array}{l}\text { Journal of } \\
\text { Clinical } \\
\text { Psychology }\end{array}$ & English & 1945 & 377 & 12 & 125.7 & 9.9 & 10.5 & 0.8 \\
\hline $\begin{array}{l}\text { Health } \\
\text { Psychology }\end{array}$ & English & 1982 & 197 & 6 & 65.7 & 11.8 & 11.0 & 2.0 \\
\hline $\begin{array}{l}\text { International } \\
\text { Journal of } \\
\text { Clinical and } \\
\text { Health } \\
\text { Psychology }\end{array}$ & $\begin{array}{l}\text { English, } \\
\text { Spanish, } \\
\text { Portuguese }\end{array}$ & 2001 & 92 & 3 & 30.7 & 3.9 & 10.2 & 1.3 \\
\hline $\begin{array}{l}\text { International } \\
\text { Journal of } \\
\text { Psychology and } \\
\text { Psychological } \\
\text { Therapy }\end{array}$ & $\begin{array}{l}\text { English, } \\
\text { Spanish }\end{array}$ & 2001 & 44 & 2 & 14.7 & 1.7 & 7.4 & 0.9 \\
\hline
\end{tabular}

Health Psychology has a large standard deviation (11.8) relative to its mean annual publication rate (65.7) owing to a doubling of its publication rate in the years 2002 and 2003 relative to 2001 .

Criterion 1: Multinational collaboration patterns. Table 2 presents the share of domestic, foreign and international articles in the total publication output for each journal as described in the previous section. 
G. BUELA-CASAL et al.: Measuring internationality

Table 2. Share of international articles for each journal

\begin{tabular}{|c|c|c|c|c|c|}
\hline \multirow[b]{2}{*}{ Journal } & \multicolumn{5}{|c|}{ Articles } \\
\hline & Year & Domestic & Foreign & International & Total \\
\hline \multirow[t]{5}{*}{ Journal of Clinical Psychology } & 2001 & 109 & 19 & 7 & 135 \\
\hline & 2002 & 106 & 14 & 10 & 130 \\
\hline & 2003 & 80 & 21 & 11 & 112 \\
\hline & Total & 295 & 54 & 28 & 377 \\
\hline & $\%$ & $78.25 \%$ & $14.32 \%$ & $7.43 \%$ & \\
\hline \multirow[t]{5}{*}{ Health Psychology } & 2001 & 43 & 5 & 1 & 49 \\
\hline & 2002 & 59 & 8 & 6 & 73 \\
\hline & 2003 & 55 & 13 & 7 & 75 \\
\hline & Total & 157 & 26 & 14 & 197 \\
\hline & $\%$ & $79.70 \%$ & $13.20 \%$ & $7.11 \%$ & \\
\hline \multirow[t]{5}{*}{$\begin{array}{l}\text { International Journal of Clinical } \\
\text { and Health Psychology }\end{array}$} & 2001 & 11 & 13 & 3 & 27 \\
\hline & 2002 & 18 & 7 & 4 & 29 \\
\hline & 2003 & 20 & 12 & 4 & 36 \\
\hline & Total & 49 & 32 & 11 & 92 \\
\hline & $\%$ & $53.26 \%$ & $34.78 \%$ & $11.96 \%$ & \\
\hline \multirow{5}{*}{$\begin{array}{l}\text { International Journal of Psychology and } \\
\text { Psychological Therapy }\end{array}$} & 2001 & 5 & 7 & 2 & 14 \\
\hline & 2002 & 10 & 0 & 3 & 13 \\
\hline & 2003 & 11 & 3 & 3 & 17 \\
\hline & Total & 26 & 10 & 8 & 44 \\
\hline & $\%$ & $59.09 \%$ & $22.73 \%$ & $18.18 \%$ & \\
\hline
\end{tabular}

We observe that the International Journal of Psychology and Psychological Therapy has the largest share of international articles $(18.18 \%)$ followed by the International Journal of Clinical and Health Psychology (11.96\%). The two US journals have a smaller share of international articles: Journal of Clinical Psychology (7.43\%) and Health Psychology (7.11\%). Also of note is that the two Spanish journals, the International Journal of Clinical and Health Psychology and the International Journal of Psychology and Psychological Therapy, having the term "international" in their titles, also have higher percentages of foreign articles $(34.78 \%$ and $22.73 \%$ respectively). However, in all four journals the share of domestic articles is high (above $50 \%$ ) compared to the share of international articles. 
Criterion 2: Multinational distribution of editorial board members. The Journal of Clinical Psychology has all five of its editorial board members from the United States, the International Journal of Clinical and Health Psychology has four editors originating from three different countries: Spain (2), Portugal (1) and Colombia (1), while the International Journal of Psychology and Psychological Therapy has nine editors from five different countries: Spain (4), USA (2), Belgium (1), Ireland (1) and Mexico (1). Data for Health Psychology is absent from this analysis as the journal refused the authors' request for data.

Thus, the International Journal of Psychology and Psychological Therapy has the more diverse country representation in its editorial board, followed by the International Journal of Clinical and Health Psychology. Based solely on this criterion, the Journal of Clinical Psychology fails to meet even the minimal, literal definition of international.

Criterion 3: Multinational distribution of associate editors. With regard to the nationalities of associate editors appointed or selected for use in the peer-review process by the editorial board, we found that the Journal of Clinical Psychology has $85.0 \%$ US editors, while the International Journal of Psychology and Psychological Therapy has 60.3\% Spanish and 22.3\% North American editors. The greatest diversity in terms of country representation is observed in the International Journal of Clinical and Health Psychology which has $54.8 \%$ editors from Spain, 9.6\% from USA, 9.6\% from Portugal, $8.2 \%$ from Colombia and $4.1 \%$ from Mexico.

To measure quantitatively this criterion, we plotted the Lorentz Curves for each journal and calculated the Gini Coefficient of inequality. The Lorentz Curves are shown in Figure 1.

The cumulative proportion of the countries (ranked according to the number of editors) is represented by the horizontal axis and the cumulative proportion of editors by the vertical axis. The straight line is called the equality line and represents a perfectly equal distribution of editors per country. Therefore, the further the Lorenz curve is from the equality line, the greater the degree of concentration and therefore inequality in terms of editors from any particular country or subset of countries.

All three of the journals for which we had data for, have a high Gini Coefficient (0.65 to 0.75 ) reflecting their poor (i.e. globally unequal) multinational distribution. It can be seen that the International Journal of Clinical and Health Psychology, lies closest to the line of equality over its whole length and thus performs best in terms of this criterion. 


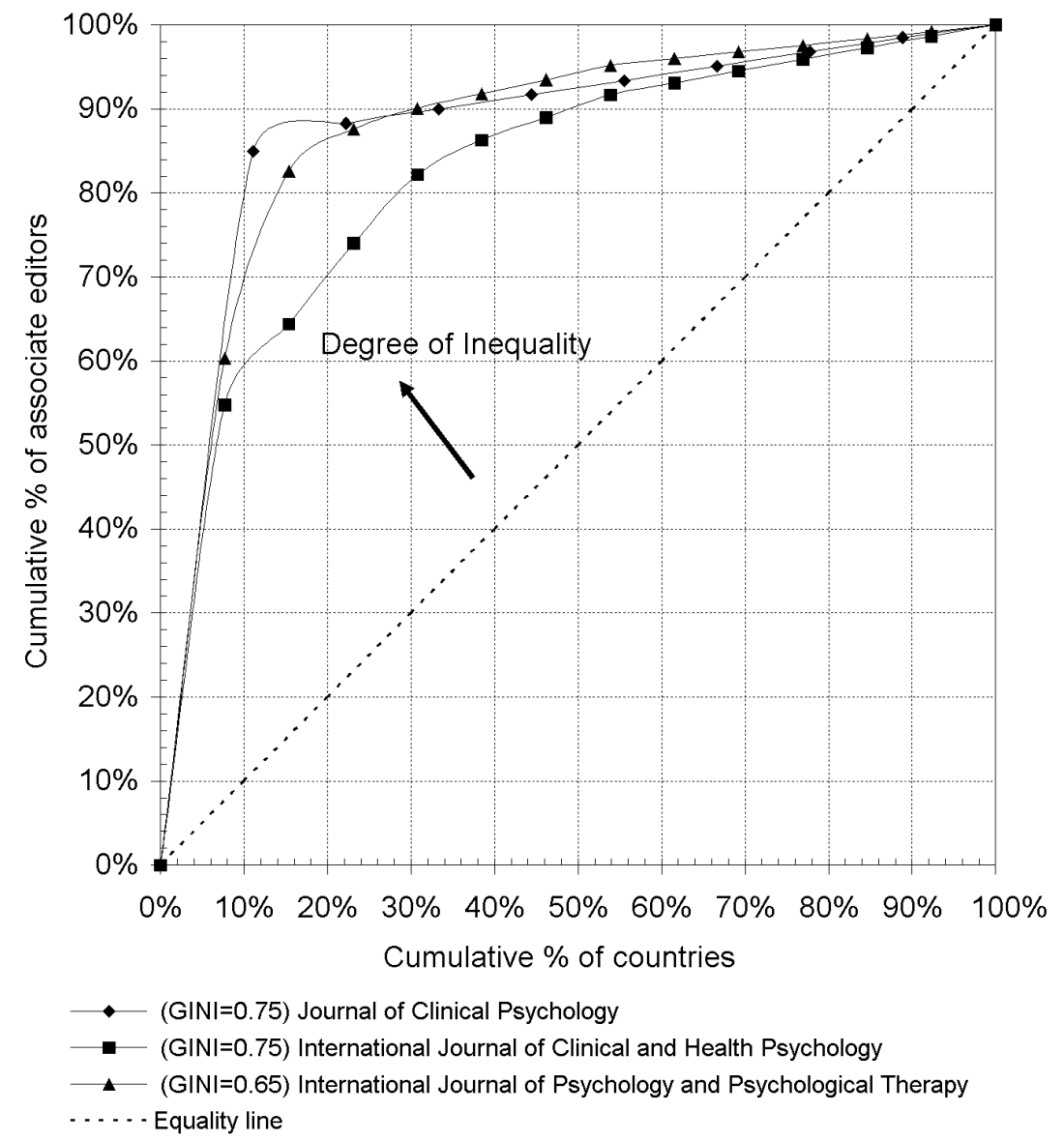

Figure 1. Lorentz curves for the Gini Coefficient measure of the inequality of the multinational distribution of associate editors

Criterion 4: Multinational distribution of authors. We ranked countries according to the number of contributing authors for the four journals. We observed a strong concentration of authors originating from a small proportion of countries. The first three ranked countries in all journals account cumulatively for $83 \%-97 \%$ of all authors. With regard to the Journal of Clinical Psychology, the USA and Italy account for $84.2 \%$ of the contributing authors even though they compromise only $8.3 \%$ of all of the countries appearing in the journal. The International Journal of Clinical and Health Psychology has a slightly smaller concentration, since the first country (Spain) accounts for less $(61.9 \%)$ authors. Nevertheless, in the same journal we note that $83.9 \%$ of all authors originate from only $25 \%$ of contributing countries. 
To evaluate quantitatively the pattern of multinational distribution of authors, we again calculated the Gini Coefficient for each journal.

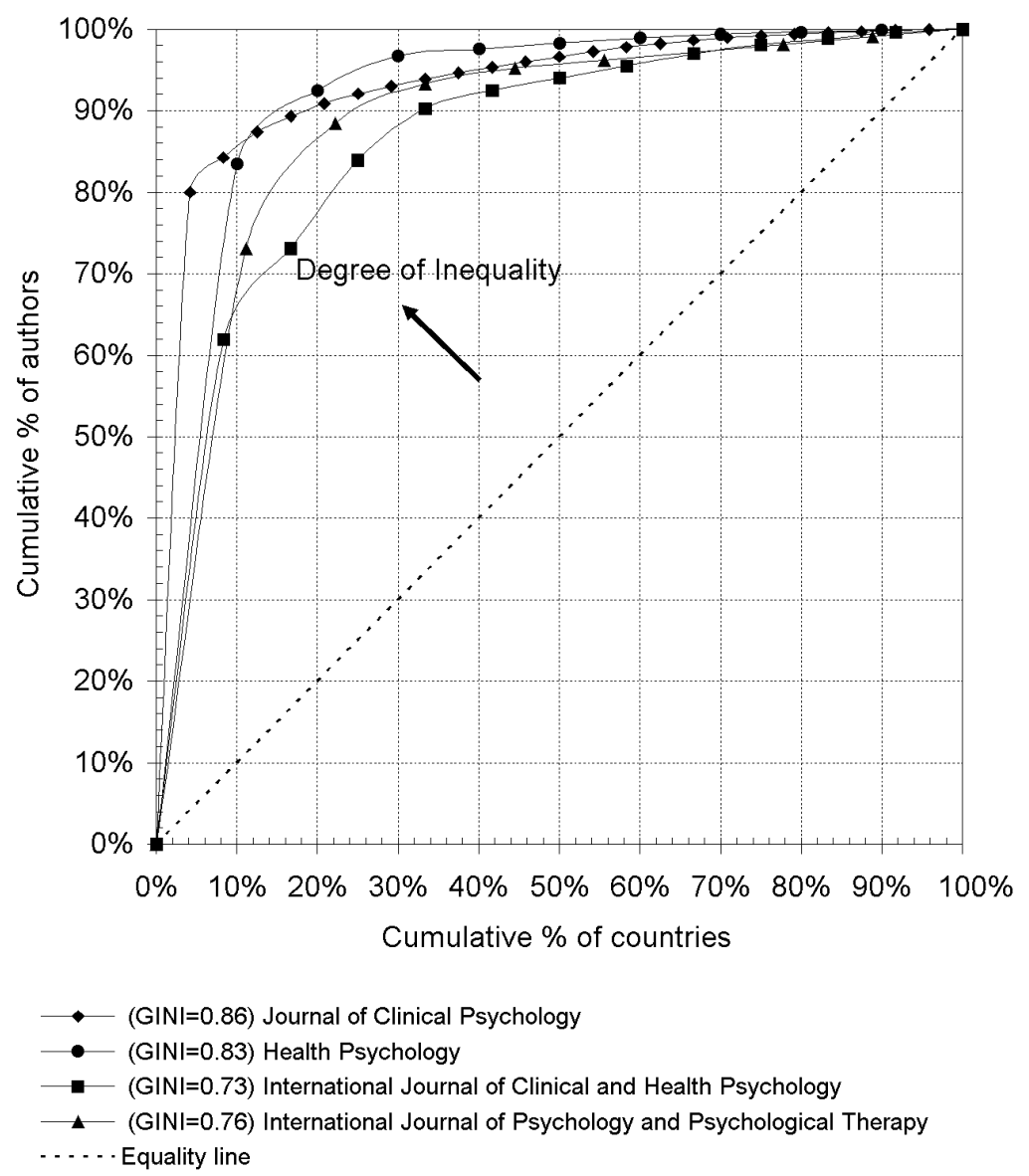

Figure 2. Lorentz curves for the Gini Coefficient measure of the inequality of the multinational distribution of authors

Figure 2 shows a great degree of concentration for all four journals, meaning that a small proportion of countries, contribute a large proportion of all published authors. The Gini Coefficients for the journals range from 0.76 to 0.86 revealing a very high degree of inequality in each case (i.e. a poor multinational distribution of authors). Once again, the Spanish journals lie closest to the line of equality over their whole length and therefore perform better in terms of this criterion. 
G. BUELA-CASAL et al.: Measuring internationality

\section{Assessment of the criteria}

In Table 3 we summarize the results of the internationality assessment of the four journals based on each of the selected criteria.

Table 3. Measurement of Journal Internationality for each criteron and journal ranking in terms of internationality

\begin{tabular}{|c|c|c|c|c|c|c|c|c|}
\hline \multirow{3}{*}{ Journal } & \multirow{2}{*}{\multicolumn{2}{|c|}{$\begin{array}{c}\text { Criterion } 1 \\
\text { Share of } \\
\text { international } \\
\text { articles }\end{array}$}} & \multicolumn{2}{|c|}{ Criterion 2} & \multicolumn{2}{|c|}{ Criterion 3} & \multicolumn{2}{|c|}{ Criterion 4} \\
\hline & & & $\begin{array}{r}\text { Number of } \\
\text { represente } \\
\text { editorial }\end{array}$ & $\begin{array}{l}\text { ntries } \\
\text { the } \\
\text { rd }\end{array}$ & $\begin{array}{r}\text { Inequ } \\
\text { distri } \\
\text { edito } \\
\text { member } \\
\text { (Gini } \text { C }\end{array}$ & $\begin{array}{l}\text { in the } \\
\text { on of } \\
\text { oard } \\
\text { country } \\
\text { cient) }\end{array}$ & $\begin{array}{r}\text { Inequa } \\
\text { distri } \\
\text { auth } \\
\text { co } \\
\text { (Gini C }\end{array}$ & $\begin{array}{l}\text { in the } \\
\text { n of } \\
\text { per } \\
\text { y } \\
\text { icient) }\end{array}$ \\
\hline & Value & Rank & Value & Rank & Value & Rank & Value & Rank \\
\hline $\begin{array}{l}\text { Journal of } \\
\text { Clinical } \\
\text { Psychology }\end{array}$ & $7.43 \%$ & 3 & $\begin{array}{c}1 \\
\text { USA }\end{array}$ & 3 & 0.75 & $2=$ & 0.86 & 4 \\
\hline $\begin{array}{l}\text { Health } \\
\quad \text { Psychology }\end{array}$ & $7.11 \%$ & 4 & - & - & - & - & 0.83 & 3 \\
\hline $\begin{array}{l}\text { International } \\
\text { Journal of } \\
\text { Clinical and } \\
\text { Health } \\
\text { Psychology }\end{array}$ & $11.96 \%$ & 2 & $\begin{array}{c}3 \\
\text { Spain } \\
\text { Portugal } \\
\text { Colombia }\end{array}$ & 2 & 0.65 & 1 & 0.73 & 1 \\
\hline $\begin{array}{l}\text { International } \\
\text { Journal of } \\
\text { Psychology } \\
\text { and } \\
\text { Psychological } \\
\text { Therapy }\end{array}$ & $18.18 \%$ & 1 & $\begin{array}{c}5 \\
\text { Spain } \\
\text { USA } \\
\text { Belgium } \\
\text { Ireland } \\
\text { Mexico }\end{array}$ & 1 & 0.75 & $2=$ & 0.76 & 2 \\
\hline
\end{tabular}

It is clear that no single criterion provides an unequivocal measure of internationality since the ranking of the journals by internationality is different for each criterion. Moreover, none of the journals are ranked first (i.e. having the highest degree of internationality) for all criteria. Internationality therefore, measured even with well-defined and quantitative criteria fails to be unambiguously defined when considered through single criterion measures as hypothesized in the previous subsection. This suggests the need for the development of a multi-criteria, single-valued and unambiguous measure of internationality in the form of a journal Internationality Index as described in the following section. 


\section{Towards an internationality index}

It is clear then, that internationality ranges from the unusual case of a journal relating to or affecting only one nation (an entirely national project having a zero degree of internationality) to the more usual case of academic journals involving and affecting more than one nation - ranging from two (the minimal case of the literal definition) to as many as 192 nations, i.e. the number of independent world states as illustrated in Figure 3.

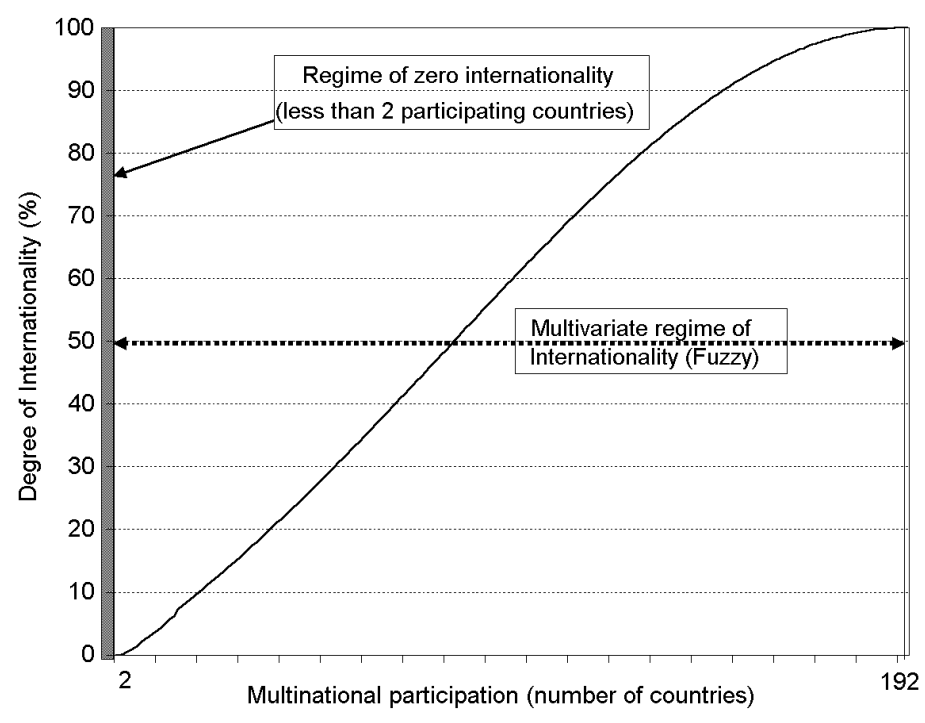

Figure 3. Internationality as a fuzzy set associated with the degree of geographical participation

The designation "international journal" is therefore imprecise in its literal sense, and incapable of differentiating quantitatively between, for example, a journal that circulates between two neighbouring countries and one with a global representation or impact.

We have also shown that the actual measure of internationality is sensitive to the criteria used in the evaluation and that no single criterion is sufficient. We propose that a journal Internationality Index can and should be constructed from a suitably-weighted combination of all relevant and quantifiable criteria. In a separate paper $^{50}$ we have shown theoretically how a neuro-fuzzy system can be used to accomplish this. Until such a study is performed, internationality remains ambiguous and undefined. 


\section{Conclusion}

In this paper, we have reviewed the contemporary view of internationality in the context of academic journal publication as well as the criteria proposed in the literature to measure its degree. We have shown how the literal definition of internationality fails to describe the degree of internationality associated with a potentially diverse range of country representation. We also argued that some of the published criteria are redundant or ambiguously defined, and how several new distinctions and definitions help to complete the list. Furthermore, we showed how even the well quantitatively defined criteria produce an ambiguous measure of internationality when considered individually.

The ambiguity of the results highlight the need for a new journal internationality index to be constructed and we have argued what structure such an index should have.

We believe that a valid and quantitative internationality index will help differentiate quality from internationality, two concepts that have overlapped and been confused until now. It has been common practice, for example, to measure publication quality using reference indices such as the Impact Factor, ${ }^{51}$ or other qualitative criteria concerning validity and utility ${ }^{52}$ or the type of methodology of the study. ${ }^{53-55}$ The confusion over the concepts has most probably arisen since publication quality is also often measured through the perceived "internationality" of journals which themselves are viewed as quality indicators of knowledge. As we have argued, however, quality and internationality are not necessarily correlated. Therefore, in the absence of an unambiguous, quantitative and holistic measure of internationality, limited perceptions based on one or another single criterion can penetrate the area of journal evaluation distorting the image of certain journals and affecting the assessment of academic quality.

The next step for scientometrists interested in measuring internationality, we believe, is to suitably weight the criteria identified here using, for example, a large-scale census of journal data. We propose that the journal internationality index might then be unambiguously constructed using the neuro-fuzzy system we have described in a companion paper. ${ }^{50}$ Until then, we reiterate that internationality and therefore the notion of an international journal have yet to be adequately defined.

We would like to thank Dr. Varvara Trachana and Professors Evaristo Jimenez and Emilio Delgado for their support and advice. 


\section{References}

1. Merriam-Webster Dictionary (Indexed \& Unabridged Edition) 2002; Available at http://www.m-w.com/cgi-bin/dictionary?book=Dictionary\&va=international\& $\mathrm{x}=0 \& \mathrm{y}=0$

2. W. Holtzman, International Council of Scientific Unions. In: A. E. KAZDIN (Ed.), Encyclopedia of Psychology. Oxford University Press, 2000, pp. 343-345.

3. B. WILPERT, International Association of Applied Psychology. In: A. E. KAZDIN (Ed.), Encyclopedia of Psychology. Oxford University Press, 2000, pp. 336-337.

4. J. M. DAVIS, International Council of Psychologists. In: A. E. KAZDIN (Ed.), Encyclopedia of Psychology. Oxford University Press, 2000, pp. 341-343.

5. R. HAmbleton, International Test Comission. In: A. E. KAZDin (Ed.), Encyclopedia of Psychology. Oxford University Press, 2000, pp. 349-350.

6. E. HASS, International Organization. In: P. B. BALTES, N. L. SMELSER (Eds), International Encyclopedia of the Social and Behavioral Science. Elsevier, 2001, pp. 7819-7824.

7. H. K. JACOBSON, International Science: Organizations and Associations. In: P. B. BALTES, N. J. SMELSER (Eds), International Encyclopedia of the Social and Behavioral Sciences. Elsevier, 2001, pp. 7834-7837.

8. K. PAWLIK, M. RosenZWEIG, The International Handbook of Psychology, Sage, London, 2000.

9. Q. JING, International psychology. In: K. PAWLIK, M. RoSENZWEIG (Eds), The International Handbook of Psychology. Sage, 2000, pp. 570-584.

10. H. P. David, J. Buchanan, International psychology. In: D. K. Freedheim, I. B. Weiner (Eds), Handbook of Psychology: History of Psychology. John Wiley and Sons, 2002, pp. 509-534.

11. M. ZiTT, E. BASSECOULARD, Internationalization of scientific journals: a measurement based on publication and citation scope, Scientometrics, 41 (1998) 255-271.

12. M. ZiTT, E. BASSECOUlARD, Internationalization of communication - a view on the evolution of scientific journals, Scientometrics, 46 (1999) 669-685.

13. G. Buela-CASAL, La psicología española y su proyección internacional. El problema del criterio: internacional, calidad y castellano y/o inglés, Papeles Del Psicólogo, 79 (2001) 53-57.

14. A. Dinkel, H. Berth, A. Borkenhagen, E. Brahler, On raising the international dissemination of german research: Does changing publication language to English attract foreign authors to publish in a German basic psychology research journal? Experimental Psychology, 51 (2004) 319-328.

15. Latindex Database. Available at http://www.latindex.unam.mx/

16. Journal Citation Reports. Available at http://www.isinet.com/products/evaltools/jcr/jcrweb/

17. W. GlÄNZEL, A. SChubert, H. J. CZERWON, A bibliometric analysis of international scientific cooperation of the European Union (1985-1995), Scientometrics, 45 (1999) 185-202.

18. W. GLÄNZEL, National characteristics in international scientific co-authorship relations, Scientometrics, 51 (2001) 69-115.

19. W. GlänZEL, C. DE LANGE, A distributional approach to multinationality measures of international scientific collaboration, Scientometrics, 54 (2002) 75-89.

20. G. Buela-Casal, A. García-Medina, M. A. Viedma, V. Godoy, S. Lorenzo, G. Torres, Factor de impacto de tres revistas españolas de psicología, Psicothema, 16 (2004) 681-689.

21. E. ECHEBURÚA, Evaluación de los sexenios en la evaluación de la actividad investigadora en el ámbito de la psicología clínica: Una primera reflexión, Análisis y Modificación de Conducta, 28 (2002) 391-404.

22. G. BuEla-CASAL, Situación actual de la productividad científica de las universidades espñaolas, International Journal of Clinical and Health Psichology, 5 (2005) 175-190.

23. V. PElechano, Valoración de la actividad científica en psicología ¿pseudoproblema, sociologismo e idealismo?, Análisis y Modificación de Conducta, 28 (2002) 323-362.

24. J. Gil Roales-Nieto, M. C. LuCiano, A la calidad por the quantity (porque la Cantidad no vale). Algunas reflexiones sobre los criterios de evaluación de la calidad de la investigación en psicología, Análisis y Modificación de Conducta, 28 (2002) 431-454. 
25. G. Buela-CASAL, La evaluación de la investigación científica: el criterio de la opinión de la mayoría, el factor de impacto, el factor de prestigio y los "Diez Mandamientos" para incrementar las citas, Análisis y Modificación de Conducta, 28 (2002) 455-475.

26. G. Buela-CASAL, Evaluación de la calidad de los artículos y de las revistas científicas. Propuesta del factor de impacto ponderado y de un índice de calidad, Psicothema, 15 (2003) 23-35.

27. J. G. ADAIR, N. Vohra, The explosion of knowledge, references, and citations: Psychology's unique response to a crisis, American Psychologist, 58 (2003) 15-23.

28. C. D. GREEN, On (not) trimming one's toenails with a bazzoka, American Psychologist, 59 (2004) 51.

29. F. Anseel, W. Duyck, W. De Baene, M. Brysbaert, Journal Impact Factors and Self-Citations: Implications for Psychology Journals, American Psychologist, 59 (2004) 49-51.

30. P. J. VAN STRIEN, The American "colonization" of northwest European social psychology after World War II, Journal of the History of the Behavioral Sciences, 33 (1997) 349-363.

31. C. F. GRAUman, Psychology in postwar Germany: The vicissitudes of internationalization, World Psychology, 3 (1997) 253-277.

32. R. ARDILA, International psychology, American Psychologist, 37 (1982) 323-329.

33. R. ARDIlA, La psicología en el futuro, Pirámide, Madrid, 2002.

34. A. UZUN, Assessing internationality of scholarly journals through foreign authorship patterns: the case of major journals in information science, and scientometrics, Scientometrics, 61 (2004) 457-465.

35. F. H. Christensen, P. IngWERSEN, I. WORMELl, Online determination of the journal impact factor and its international properties, Scientometrics, 40 (1997) 529-540.

36. J. C. Sierra, I. ZubeIDAT, Análisis bibliométrico de la revista Journal of Sex and Marital Therapy, International Journal of Clinical and Health Psychology, 2 (2002) 351-362.

37. D. Agudelo, J. Bretón-López, G. Buela-Casal, Análisis comparativo de las revistas de Psicología de la Salud editadas en castellano, Revista Latinoamericana de Psicología, 35 (2003) 359-377.

38. D. Agudelo, J. Bretón-López, G. Buela-Casal, Análisis bibliométrico de las revistas de Psicología Clínica editadas en castellano, Psicothema, 14 (2003) 507-516.

39. D. Agudelo, J. Bretón-López, G. Buela-Casal, Análisis bibliométrico de las revistas relacionadas con Psicología de la salud editadas en castellano, Salud Mental, 27 (2004) 70-85.

40. J. Bretón-López, G. Buela-CAsal, Análisis comparativo de las revistas de Psicología Clínica editadas en castellano, Revista Mexicana de Psicología, 20 (2003) 141-155.

41. G. Melin, O. Persson, Studying research collaboration using co-authorships, Scientometrics, 36 (1996) $363-377$.

42. N. NARVAEZ-Berthelemot, An index to measure the international collaboration of developing countries based on the participation of national institutions - the case of Latin-America, Scientometrics, 34 (1995) 37-44.

43. T. Luukkonen, R. J. W. Tijssen, O. Persson, G. Sivertsen, The measurement of international scientific collaboration, Scientometrics, 28 (1993) 15-36.

44. G. MELIN, Impact of national size on research collaboration - A comparison between Northern European and American universities, Scientometrics, 46 (1999) 161-170.

45. J. Rey-Rocha, M. J. Martin-Sempere, Patterns of the foreign contributions in some domestic vs. international journals on Earth Sciences, Scientometrics, 59 (2004) 95-115.

46. J. ViRUES-ORTEGA, S. N. HAYNES, Functional analysis in behavioral therapy: Behavioral foundations and clinical application, International Journal of Clinical and Health Psychology, 5 (2005) 567-587.

47. J. ViRues-ORTEGA, Causes of unity and disunity in Psychology and Behaviorism: An encounter with Arthur W. Staats' Psychological Behaviorism. International Journal of Clinical and Health Psychology, 5 (2005) 161-173.

48. P. M. Dixon, J. Weiner, T. Mitchellolds, R. Woodley, Bootstrapping the Gini coefficient of inequality, Ecology , 68 (1987) 1548-1551.

49. http://astro.ft.uam.es/ mtaylor/data.pdf

50. P. Perakakis, M. Taylor, G. Buela-Casal, P. CheCA, A neuro-fuzzy system to calculate a journal internationality index, Symposium on Fuzzy Logic and Soft Computing, Proc. CEDI (2005), Granada, Spain. Available online at http://astro.ft.uam.es/ mtaylor/CEDI2005.pdf 
51. E. GARFIELD, The meaning of the Impact Factor, International Journal of Clinical and Health Psychology, 3 (2003) 363-369.

52. G. Buela-CASAL, J. R. FernándeZ-Hermida, W. LóPeZ, IBEINDEX: Indice iberoamericano de evaluación de publicaciones científicas, Infocop, 84 (2003) 41-44.

53. J. M. RAMOS, A. CATENA, Normas para la elaboración y revisión de artículos originales experienciales en ciencias del comportamiento, International Journal of Clinical and Health Psichology, 4 (2004) 173-189.

54. H. CarReterdo-Dios, C. Perez, Normas para el desarrollo y revisión de estudios instrumentales, International Journal of Clinical and Health Psychology, 5 (2005) 521-551.

55. I. Montero, O. G. LeON, Sistemas de clasificicación del método en los informes de investigación en Psicología, International Journal of Clinical and Health Psychology, 5 (2005) 99-114. 